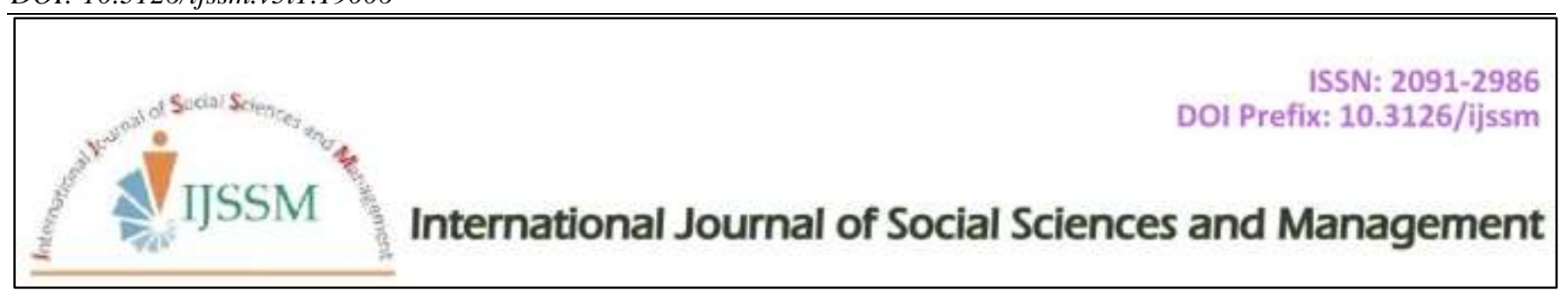

Research Article

\title{
Water Institutional Arrangements of FalajAl Daris in the Sultanate of Oman
}

\author{
Ahmed Salim Al-Marshoudi ${ }^{1 *}$ \\ Agriculture Economic, Wye College, University of London, UK
}

\begin{abstract}
Oman, which is located on the Southern East of Arabian Peninsula, classified as holding a semi-arid climate with an average annual rainfall of $100 \mathrm{~mm}$. Therefore, agricultural production in Oman is fully dependent in irrigation. More than one third is supplied by the ancient aflaj (sing. Falaj), which provide $680 \times 10^{6} \mathrm{~m}^{3}$ of water per year and irrigate of an area of 26,500 ha. There is two commonly known definition of the aflaj; the locally defined from the classic Arabic root as to divide the water among its shareholders. In addition, the modern technical definition as trenches and tunnels, which are dug in the ground, to convey the accumulated rainfall water table to the irrigated area in the villages. This study explore some of the existing institutional arrangements found within Falajdaris, at the waliyat (city) of Nizwalocated in the Dakhillya governmental, Sultanate of Oman. This study uses mainly face-To-face interviews with local administrative falaj agents to explore and discuss the most operated mechanized of the institutional arrangements. The study concluded that there is strong relationship between FalajDaris institutional arrangements development and physical water variability.
\end{abstract}

Keywords: falaj systems; institutional arrangements; water ownerships; water rights

\section{Introduction}

Oman classified under arid and semi arid climatically zones which depend entily on groundwater and desalination plants to fulfil its growing water demand. Historically the Omani innovated a well-known ancient irrigation system locally referred as aflaj to manage their scarce water resources under a harsh environment. In the past, the aflaj systems considered as the backbone of the village life, not only provided water for domestic and agricultural uses, but also encouraged settlers to participate on day-to-day water transactional activities such as the weekly or annually traditional water market, selling of water rights and weekly or annually renting water rights. However, still some of these activities take place in Oman until present time. Hence, the main aim of this study is to document and explore some of these institutional arrangements. Falaj Daris, at the waliyat of Nizwa located in the Interiold region, Sultanate of Oman was taken as a comprehensive detailed case study to examine to what extent have the existing surrounding hydro geological environment affected the historical development institutional arrangements of the ancient falaj systems?

The theory that water institutional arrangements might be reflected upon watercourse physical variability (Young,

\section{Cite this article as:}

A.S. Al-Marshoudi (2018) Int. J. Soc. Sc. Manage. Vol. 5, Issue-1: 31-42. DOI: 10.3126/ijssm.v5i1.19006

$1 *$ Corresponding author

Ahmed Salim Al-Marshoudi,

Agriculture Economic, Wye College, University of London, UK

Email: almarshoudi4@gmail.com

Peer reviewed under authority of IJSSM

(C) 2018 International Journal of Social Sciences and Management

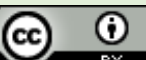

This is an open access article \& it is licensed under a Creative Commons Attribution 4.0 International License (https://creativecommons.org/licenses/by/4.0/) 
1986). Generally, aflaj water flow continuously day and night, however, it varies according to main rainfall rate on the flaj zone mountainous areas. Therefore, falaj institutional arrangement required to be initiated with accordance to this phonemia. To the extent such relationship extensively reviewed in the literatures, this study focused through the use of the above-mentioned flaj to document and explores this relationship. Thus, the main objective of the study is examine if relationship between the falaj Daris water flow and its existing institutional arrangement and then to document these institutions using available watercourse literature review. Based on these two objectives, the further scope of the study are:

1. To analyze the collected time serial date of the falaj Daris water rights

2. To presented the primary data collected through interviews

3. To present the secondary recorded data obtained.

\section{Theoretical Consideration}

John Wilkinson was probably the first Western on demonstrated the evolution of the basic falaj organization based on the analysis, falajmalki in Izki village(Wilkinson, 1977) He showed how the villagers managed water resources during drought period by arguing that during abundance of water supply, they tend to open other channel of the primary network. He stated, "Where there is considerable variation in base flow some of the channels are opened only when water is plentiful" (p. 99). Similarly, Birks (1977) illustrated the local traditional-strategic management which was taken by villagers during severe drought in wadi Hawashniah in 1977. This falaj had one main channel entering the village and then splitting into two supplying different parts of the village. In normal years, both of these canals were open. Birks found that during drought period with low flow one canal was closed. He further pointed out that the consequence of this drought response only supplying water in one channel at a time was that the cycle of irrigation for each field was lengthened from seven to 14 days.

It is well recognised that water is considered as a prerequisite of all sorts of social as well as economic development. However, in the past water used to be referred as a free good, by which this has been replaced by new perspective that water can be treated either as social good or economic commodity (Randall, 1981; Milliman, 1959; Saleth and Dinar, 2005). First those who hold the view that water is a social good have looked into several factors including its necessity to life and perquisite of society social development (Araral, 2009; Brajer and Martin, 1990) and its association with agrarian and industrial revolution (Rose, 1990). While those who hold the view that water can be considered as an economic commodity stem from the fact that water is becoming scarce and its demand is increasing.
It is not the aim this study to debate which is right or wrong, it is surface to say that the economical argument in considering water as an exchangeable commodity is the fact that price of water will reflect its true scarcity and its opportunity cost, in other words, the price that the marginal user is willing to pay (Perry, 2001; Randall, 1981).

Reviewing literature the issue of water management in general term extensively discussed by researchers. One can summarise this discussion into two main themes:

- Introducing what is known as 'economical instrument' such as water prices or water market.

- The possibility to assert private ownership to water rights.

It is apparent from the fast body of literatures that these two issues discussed sometime within the context of 1). Common-pool resource and sometimes attempted to associate the historical matter related to the 2).Concept of 'water appropriation' and associated rules (Bromley, 1982; Dales, 1968; Easter et al., 1999). (Randall, 1981, Milliman, 1965). While the former was used to provide classified property rights which may be reflected by the physical variation of the resource, the historical water appropriation was used to analyse the associated water law within a legal context.(Randall, 1983, Milliman, 1959). For example, Randall (1983) discussed the issue of private ownership within the context of differentiating between public goods and common resources on the ground that physical nature of the resources is to be blamed for the difficulty of asserting a private ownership(pg. 133).

We are fully aware that two main concepts exchangeable used as evaluative criteria to analyse any watercourse. These are:

- Fairness (equity) by which to distribute water among shareholders (Easter et al, 1999, Dietz, 2003)

- Efficiency to the extent of how to utilize water productively (Araral, 2009, Bjornlund, 2003 ).

The aim of these two evaluative criteria is to find the most suitable water institutional arrangements (Saleth and Dinar, 2005). It is well recognised that developing a weak institutional arrangements to regulate any watercourse rights can easily create a complex management problems. For instance, Branger and Martin(1990) pointed out that any possible divergence between social and private benefit result in the failure of a market system. Bromely (1982) pointed out that the concept of Pareto optimally and economic efficiency analysis is not an adequate basis for guiding collective action. He is in favour to analyse the problem from social context. Therefore, establishing a fair system with well-defined property rights associated with community participation in decision-making is expected to 
be the most important priority of any institutional arrangements (Dietz, 2003). To do this some scholars have argued to incorporate knowledge relating to culture, beliefs (Rutherford, 1995; Walliman, 2006) and customs (North, 1991).

\section{Water Resources Management in Oman}

In the absence of alternative supplies of surface water in Oman, groundwater resources form the backbone of local farming economies. The current water supply and associated crop cultivation practices found within two main farming types, both of which use groundwater aquifer. The first and the most modernized type are practiced by digging a well which is normally owned by individual farmers. The second is through natural flows by the use of man-made tunnels and channels known as falaj (plural aflaj) systems. This classification dictates details understanding of the two types as follows: A farm with its own private owned individual well is calledmazraliterately means a farm, while farms that receive water from a public falaj are called amwal. This Arabic word, amwal, which is literally means 'public wealth' in its plural form, indicate clearly the falaj system operate within a community property structure. Second, the community assets and property can be considered as a legal boundary which includes walls, channels, bridges, building and gardens. Several regions over the northern part of the country rely heavily upon a single community-owned falaj for irrigating their date gardens and other annual crops. This requires a high degree of social control and cooperation to maintain the system, keep it running and to manage its distributive water rights.

Wilkinson $(1977)^{2}$ provided a detailed illustrative settlement over arid region of the Arabian Peninsula using aflaj as an example, in particular Izki village. Later studies have touched upon other economic as well as technical aspects (Abdel Rahmnn and Omezzine, 1996; Al-Ghafri, 2001; Norman et al., 1997). More recent studies incorporated more of the water management social issues; Abdel Rahmnn and Omezzine (1996) and Zekri and AlMarshudi (2008) placed the system within the context of a competitive market and tradable water right. As far as FalajDaris is concerned (Megdiche-Kharrat et al., 2016) and (Megdiche-Kharrat et al., 2017)have provided a brief an illustrative historical and administrative account

\section{Methods}

This study is a part of a comprehensive research study included the largest and most famous aflaj in the area. It is believed that these hold some indigenous knowledge with regard to study objective on the issue of water institutional arrangements. This study went through several steps:
1. Multiple visits to the study area. This has been carried out for two reasons. 1). To develop cultural understanding and norms of conduct with the Omani people whom will be interviewed for obtain information fulfilling the study objective. 2). Able to develop the research field work framework in terms sort of question needed, type of recording instrument to be used, number of important associated personal to interview and any of the official governmental bodies associated to aflaj to be included.

2. Obtained field work fund from the yearly funded Omani government project related to Oman or the dry environment countries and managed by the 'Thesiger Oman Fellowship, Royal Geographical Society, UK. (see the following site for the year 2009 and the title as shown "'An analysis of institutional arrangements of the falaj irrigation systems in Oman' An exploration of the distinctive institutional settings of the Omani falaj system, developed within a closed society, and the consequential demand for water as a result of the modern

technology.http://www.rgs.org/OurWork/Grants/ Research/Thesiger-Oman+Fellowships.htm

3. Because the waliyat of Nizwa is away from the Capital (about $160 \mathrm{~km}$ ) and several visits were required to collect the data, a communications office was required. The University of Nizwa administrative body was approached for a request of an office with modern communication facilities. It helped greatly in saving expanses which were calculated for transportation from the capital city (Muscat) over several trips. Also, created some sort of academicals face-to-face feedback, as Prof. Omezine, Abdullah, x.Dean and Prof. Powers, D. , asst. dean were asked by supervisor to provide weekly session for answering questions raised from the field activity.

4. One of the key private members as far as the field survey is concerned is the wakeel. A list of their contact numbers and names is normally available for each district'smayor (governor), locally known as 'walis'. Several official letters were sent through the head of the College of Commerce, University of Nizwa, to each associated local walis, who keeps details of the falaj wakeel, asking for permission to interview the wakeels and to obtain names and contact details.

5. A complete set of questions was formulated for each wakeel covering the main topic concerning
${ }^{2}$ It is worth noting that Wilkinson's analysis placed the system within an organizational framework and he stated that "the aflaj system is an organization for distributing water amongst those who have rights to it and to divide the property to water" (pg. 94). He also stated that "the word falaj is a generic term for a complete irrigation system" (Pg. 74). 
the classification of falaj property rights; in particular, how much falaj rights were devoted toward common rights, private and quasi- rights. They were also asked whether there was an auctioning water market and how often it is operated and where ${ }^{3}$

6. After completion of the responses to all the questions, detailed records were obtained concerning a list of the property rights for all stakeholders, auctioning water prices and other related data. Some of the respondents were not ready at the proposed time of the first visit and in some cases data held by other members within the administrative falaj structure was obtained instead. Thus, names and contact address for other members of the local administrative committee were obtained. Due to difficulties in following up the list of property rights or understanding some of the auctioning terms used in relation to the water market, further visits were conducted to obtain clarification of these issues. Later on a great deal of material required similar clarification either from the wakeel himself or from other members, and in some cases interviews were completed via telephone calls.

The secondary data which for this study included official data on falaj flow, water auctioning prices and climatic data on rainfall and temperature. These were obtained from either the traditional recording books held by the wakeels or auctioneers

\section{Study Area}

Falaj daris considered to be among the five Omani aflaj inscribed in the World Heritage List since July 2006. It was selected for several reasons. First, it believed to hold ancient indigenous knowledge with regard to the water institutional arrangements. Second, it is popular in its water flow reaching a level of 2000 litres per second. According to the last inventory of aflaj, the total irrigated area of falaj Daris was $1,715,502$ square meters, which can be extended to an area of 2,382,642 square meters (In fact sometime this refer to as falaj zone of 2,382,642 square meters (MRMWR, 2000).

\section{Results}

Oman has almost two distinct topographic areas; the mountainous zone areas, by which reaching altitude of 200$300 \mathrm{~m}$, and the coastal plain areas descending to the sea level (Megdiche-Kharrat et al., 2017). It is the mountainous zone area where by most of the aflaj systems are found, specifically in the northern part of the country (see Fig. 1). It is well recognised that there are two important elements very much associated with the context of the systems; these are:

- The significant of the natural setting characterized by mountains and oases, of which have reflected upon the water supply.

- The development of legal and social organizational setting which based on belief and customary rules.

These have assisted greatly on the formation of what known as "settlements" or villages around legal known boundary. Hence Falaj Daris was constructed in accordance with topography of the area by which has divided the waliyah of Nizwa into two main sections; the upstream, locally referred to as the Al allayah, and the downstream, locally referred to as the Asfayllah.
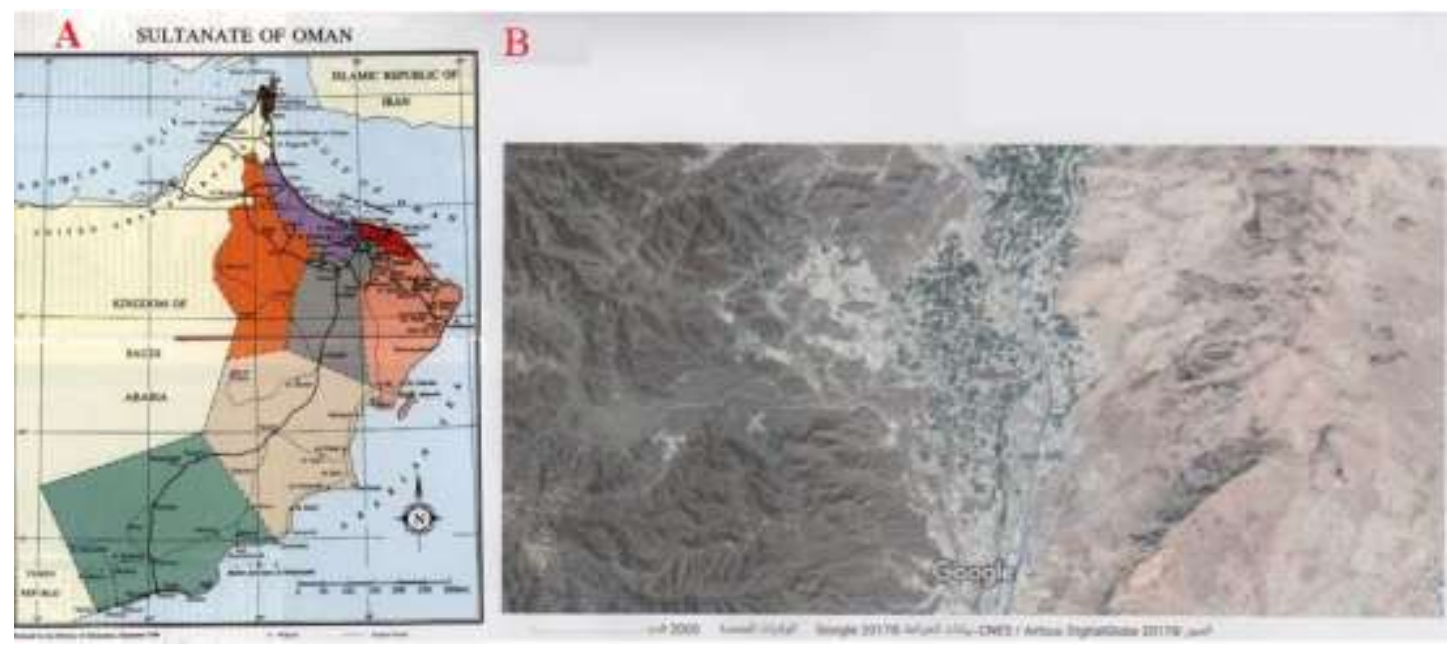

Fig. 1: A. The Sultanate of Oman map; B. The location of the study area.

${ }^{3}$ Four interviews were conducted; two with the two wakeels $\mathrm{Mr}$. Khamis Al Daishi, who responsible about one third of the private water right owners and Mr. Fahid Al Tobi who responsible with the other third and the governmental part-time employer who responsible about the bayt-mal water rights 


\section{Location and History of Falaj Daris}

Falaj Daris, located near the ancient city of Nizwa at coordinate of N22 5956 E57 3209.08 (see fig. 2) (http://whc.unesco.org/en/list/1207/multiple=1\&unique_nu mber=1384), is one of several aflaj constructed by the Yrubi's Imamate in the seventeenth century (when Sultan b. Sayf al-Yarubi was Imam, from 1650 to 1660) (Nash, 2008). In fact during the author's field survey the current financial wakeel, Nasser Bin Salim Mohammed AlKharousi, recounted the story of its construction from two perspectives. First, he indicated that the initial idea of digging the currently operating mother well was an attempt to utilize a high aquifer water level in an area that used to be cultivated by sugar cane demanding less irrigation. Second, there were three small falaj namely; falaj Al-mairi, falajDouse and falajMaideth, which had small irrigated areas. According to this wakeel, after consultation with the local people, the Imam ordered that these aflaj close to the irrigated area of Darisought to be joined with this newly constructed falaj. Thus, he indicated that the name Daris literally means to takeover. In addition, the Imam thought to substitute all rights belonging to these aflaj with rights from falajDaris.

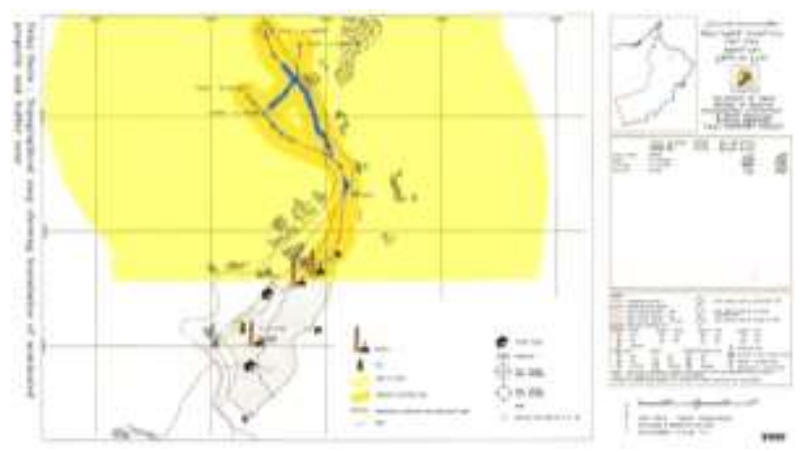

Fig. 2: Falaj Daris lay out map, Al allayah and Asfayllah. [Source

(http://whc.unesco.org/en/list/1207/multiple=1\&unique_number=1384)]

\section{Falaj Administrative Structure}

The wakeel, Mr. Hilal b. Saif Al-Ismaili was first contacted by phone and informed of a detailed study which included the falaj that he is administrating. He responded positively, and asked the author to meet at his house which is located at the Allayah village, city of Nizwa (see figure 3). During this interview overview insight concerning falajDariswater is distribution (baddah and raddah local tern see below) and water rights structure have been provided. It is worth noting that several interviews were conducted with him for two main reasons:

${ }^{4}$ Originally qiyaswere derived from the process of measuring a thing so that it is used to reflect a volume, as in the past they tended to use a container made of copper with unit lines marked on the inside. Qiyasis
- The complexity of water management found within darisfalaj because this falaj is regarded as the largest in the region and thus possesses a large number of property rights, which are distributed among different shareholders (this shall be discussed in details below).

- It is true that this wakil has received little or no education but he has great knowledge concerning water management that probably no one else in the area can provide. It is normal in Oman for this elderly generation, together with the vast majority, to be illiterate since formal education only started in 1970 with just a few schools. This ought to be viewed positively because most of the information was provided dealing with matters of custom which is passed by oral tradition from one generation to another.

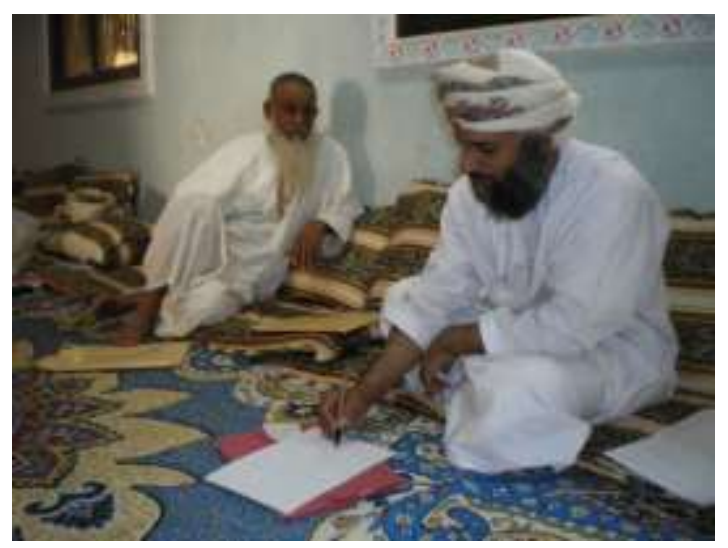

Fig. 3: Detailed interview with wakil Hilal Al-Ismaili

After interviewing the first wakil; Hilal b. Saif Al-Ismaili' he introduced us to the second wakil Nasser Bin Salim Mohammed Al-Kharousi' who provided more details of irrigated areas and better explanatory terms for the baddah and raddah ( see below) Finally, the Areefs were introduced.

\section{Falaj Daris: Water Circulation Mechanism}

Raddah is a local customary term which means 'number of turns' (plural raddat). It is considered as the main component of the distribution and allocation system known by custom as number of raddat using plural term, which means 'rotation over a defined period', normally a week or more. In the literature it has been indicated repeatedly that dawrah forms the principle of the distribution of water in aflaj (Wilkinson, 1977; Al-Ghafri, 2001). According to Mr. Nasser Bin Salim Mohammed Al-Kharousi', two measuring units are commonly used within the context of the falaj distribution/allocation system; qiyas $^{4}$ and ather. ${ }^{5}$

considered as the smallest unit within the context of the falaj distributive system.

${ }^{5}$ Originally an ather was derived from the shade from a stick which is placed on a flat area. The movement of the shade over this area as reflected 
Originally, these units were as follows: A three-meter high stick is anchored at the centre of a flat area where there is little shade to prevent the sun from shining directly on the stick. Then the area to the west and east of the stick is divided into 24 sections; these divisions are equal to one ather (30 minutes). Now, each atheris divided into 24 qiyas. So each 24 hour period consists of 48 athers.

To appreciate a full understanding of the use of these units, as far as falajDaris is concerned; an attempt is made to illustrate what is understood by the local people during this study survey as follows:

1. Wakil Mr. Hilal orally stated that the falajdaris water flow circulated over two main areas in Nizwa; Al-lahlayah (upper stream areas) and the Safaalh (downstream areas). Then he indicated the amount of water flow to each in the locally used measuring unit baddah; stated' the Al-lahlayah hold 6 baddah while Safaalhhold the remaining 11 of the total 17 baddah for all darisfalaj water circulation. Thus, in summary falajDaris has a total of 17baddah which are distributed among all shareholders over a period of eight raddah, which is equivalent to eight days.

2. Wakil Mr. Nasserstated 'there are four major areas by which falajDaris water is irrigated in sequence. These are well known irrigated places customary and legally recognized within falaj zone area: $A l$ - lahlayah (upstream areas), Mudah, Safaalh (downstream areas), and Bayt-al-mal(state-own water). These areas are then sub-divided into other areas forming eight days radah circulation. Tables 1 and 2 summarise the obtained information from the two wakils ${ }^{6}$.

3. For each of the four main areas a distributing agent, locally referred to as the Areef is appointed by the owners of the water rights. The areef has two major functions. First, he is responsible for giving each holder of the water right ather (see below). Second, he is responsible for allowing the falaj water to flow to the next area once he has delivered all the athers belong to the water right holders entitled on the first area.

4. Since falaj water continuously flows day and night, the time period of the complete day (24 hours) represents a distributive raddah (turn). This raddahis normally assigned to a particular irrigated area well-known name by which attached to it a group of shareholders (these can be refereed as cluster). This shall be discussed below. In addition, to provide a fair distributive system, since it is more convenient to irrigate during day time than night, the raddah is divided into two main equal parts: 'night baddah' and 'day time baddah, which both hold in principle 12 hours water circulation each.

Table 1: General first insight obtained information

\begin{tabular}{|c|c|c|}
\hline & & raddat known names \\
\hline \multirow[t]{4}{*}{ Upstream areas } & day1 & bayt-al-mal \\
\hline & day 2 & upstream \\
\hline & day3 & Kharf Khaleefah \\
\hline & day4 & muftah al-kindi \\
\hline \multirow[t]{4}{*}{ Down stream areas } & day5 & bayt el mal ; downstream secto \\
\hline & day6 & mosques \\
\hline & day 7 & mudah \\
\hline & day8 & falaj renting \\
\hline rights distrbution & baddah & \\
\hline \multicolumn{3}{|c|}{ upsteam sector; halays } \\
\hline waqf & 5 & \\
\hline private & 1 & \\
\hline sub-total & 6 & \\
\hline \multicolumn{3}{|c|}{ Downstream sector, Sofailah } \\
\hline falaj & 2 & \\
\hline bayt el mal & 4 & \\
\hline waqf & 3.5 & \\
\hline private & 1.5 & \\
\hline sub-total & 11 & \\
\hline Total & 17 & \\
\hline
\end{tabular}

by the movement of the sun used to represent a water flow over the area over approximately 30 minutes.
Table while the information received from Hilal b. Saif Al-Ismaili illustrated below

${ }^{6}$ Note the information provided by Nasser Bin Salim Mohammed AlKharousi' regarding the irrigated zone area presented in the first part of 
Table 2: The four main falaj daris water rights types

\begin{tabular}{|l|c|c|}
\hline & Badah & Ather \\
\hline upsteam sector; al-lahlayah & & 144 \\
\hline Waqf & 4 & \\
\hline Private & 2 & \\
\hline & & \\
\hline Downstream sector, safaalh & & 264 \\
\hline Falaj & 2 & \\
\hline$\quad$ bayt-el-mal & 4 & \\
\hline Waqf & 2.5 & \\
\hline Private & 2.5 & \\
\hline & & \\
\hline & & \\
\hline Total & 17 & 408 \\
\hline
\end{tabular}

Table 3: The eight days flaj Daris water circulation (locally the eight raddat)

\begin{tabular}{|l|l|}
\hline & irrigated known- areas \\
\hline day1 & bayt-el-mal ; downstream sector \\
\hline day2 & bayt-el-mal ; upstream sector \\
\hline day3 & upstream \\
\hline day4 & Kharf Khaleefah \\
\hline day5 & muftah al-kindi \\
\hline day6 & mosques \\
\hline day7 & madah \\
\hline day8 & falaj renting \\
\hline
\end{tabular}

In addition, from the information given in the two Tables above, there are four main types of water rights exist which can be placed under the four known categories of property rights: common, quasi- public, public and private. This research will clarify some of the distinctions between these different categories from the Omani context. We are aware here that we listed four water right types in Table 2, but the falaj right can be described under the common as this shall be illustrated below.

\section{Falaj Common Right}

These rights are different for the owned rights, which shall be discussed under the heading private rights. In fact, we called them common because in one hand they are opened to all shareholder categories to rent in order to use only the water for a period of time, usually once a week; whereas, on the other hand, they are belong only to the falj property assets in the sense. They normally put through a process of biding through tradition water market in order to collect income which then used to maintain the system.

In fact, the survey revealed that these rights are normally rented either weekly or annually. Below are detail accounts of the finding.

\section{The weekly auctioned}

This is the most common auctioned right and possesses two particular features. First, it is closely linked to the water distributional raddat circulation (see Table 3 and 4). Here a whole day is assigned for falaj income generation and is mainly used for its day-to-day maintenance. Second, $M r$. Hilal Al-Esmaili orally stated an important institutional arrangement by which the weekly auctioning process must be regulated. . He stated this by indicated two main scenario 1) During scarcity of water flow, the common falaj right has $32 r u b^{\prime} a^{7}, 2$ ) During abundant of water flow then falajDaris has only $16 r u b$ ' $a$ and the remaining units, that is the excess of water, must be passed out from the main channel normally to the wadis (oasis).

Table 4: Summary of the total falaj Daris water rights found

\begin{tabular}{|c|c|c|c|}
\hline & baddah & ather & $\%$ \\
\hline \multicolumn{4}{|l|}{ falaj renting rights } \\
\hline annual (murboutah) & 0.1 & 2.5 & \\
\hline weekly & 2 & 48 & \\
\hline Waqf rights & 8.5 & & \\
\hline Mosques & & 83 & \\
\hline Schools & & 29 & \\
\hline poors & & 10 & \\
\hline others & & 82 & \\
\hline Private rights & 4.4 & 58.5 & \\
\hline Bayt-al-mal & 2 & 96 & \\
\hline \multicolumn{4}{|l|}{ Summary } \\
\hline private & & 58.5 & $14 \%$ \\
\hline falaj renting & & 49.5 & $12 \%$ \\
\hline Waqf & & 204 & $50 \%$ \\
\hline Batyt-al-mal & & 96 & $24 \%$ \\
\hline Total & 17 & 408 & $100 \%$ \\
\hline
\end{tabular}

To appreciate what is $r u b^{\prime} a$ and how is measured and how is operated over auctioning markets, above all to appreciate the practicality of the above mentioed institution, time series data concerning actual auctioning process were analysed. This obtained from a person locally known as khatab (recorder), heis locally known by the term 'dafter', literally meaning recording books, always present during the auctioning processand he was introduced. His main function is to recorder an important information associated with the biding process; include the irrigated time local names (first of night, mid of night etc), the implicit channel (kiz) division (whether during abundant water flow, use four kiz or drought flow using only two, the potential bidder name and bidding prices. We asked the khatab to view these books and, if possible, to photocopy some of its pages for the purpose of the study. He agreed on the condition that the contents remain confidential and that they were returned quickly.

${ }^{7}$ Water quantity measuring unit equivalent to three hours irrigated period and in plain English means quarter.

Full text of this paper can be downloaded online at www.ijssm.org/ \&http://nepjol.info/index.php/IJSSM/issue/archive 
Table 5: The two selected period for the night common right; from the auctioned recorded book

\begin{tabular}{|c|c|c|c|c|c|c|}
\hline & \multicolumn{3}{|c|}{ Sunday 17/10/2004 } & \multicolumn{3}{|c|}{ Thursday 5/Feb/2009 } \\
\hline & & prices RO & Rented to & & prices RO & Rented to \\
\hline \multirow[t]{4}{*}{ First of night } & kiz_1 & 1.5 & farmer_1 & kiz_1 & 19.7 & farmer_2 \\
\hline & Kiz2 & 1.5 & farmer_1 & Kiz2 & 15 & farmer_13 \\
\hline & Kiz3 & 1.5 & farmer_1 & & & \\
\hline & Kiz4 & 1.5 & farmer_2 & & & \\
\hline \multicolumn{7}{|c|}{ Second of night } \\
\hline & kiz_1 & 1.4 & farmer_3 & kiz_1 & 10 & farmer_16 \\
\hline & Kiz2 & 1.4 & farmer_3 & Kiz2 & 10 & farmer_16 \\
\hline & Kiz3 & 1.4 & farmer_4 & & & \\
\hline & Kiz4 & 1.4 & farmer_2 & & & \\
\hline \multicolumn{7}{|l|}{ Mid of night } \\
\hline & kiz_1 & 1.4 & farmer_2 & kiz_1 & 10 & farmer_17 \\
\hline & Kiz2 & 1.4 & farmer_5 & Kiz2 & 10 & farmer_18 \\
\hline & Kiz3 & 1.4 & farmer_6 & & & \\
\hline & Kiz4 & 0.5 & farmer_7 & & & \\
\hline \multicolumn{7}{|l|}{ Last of night } \\
\hline & kiz_1 & 0.7 & farmer_8 & kiz_1 & 10 & farmer_18 \\
\hline & Kiz2 & 0.7 & farmer_8 & Kiz2 & 10 & farmer_17 \\
\hline & Kiz3 & 0.7 & farmer_9 & & & \\
\hline & Kiz4 & 0.7 & farmer_10 & & & \\
\hline
\end{tabular}

Table 6: The two selected period for the day-time common right; from the auctioned recorded book

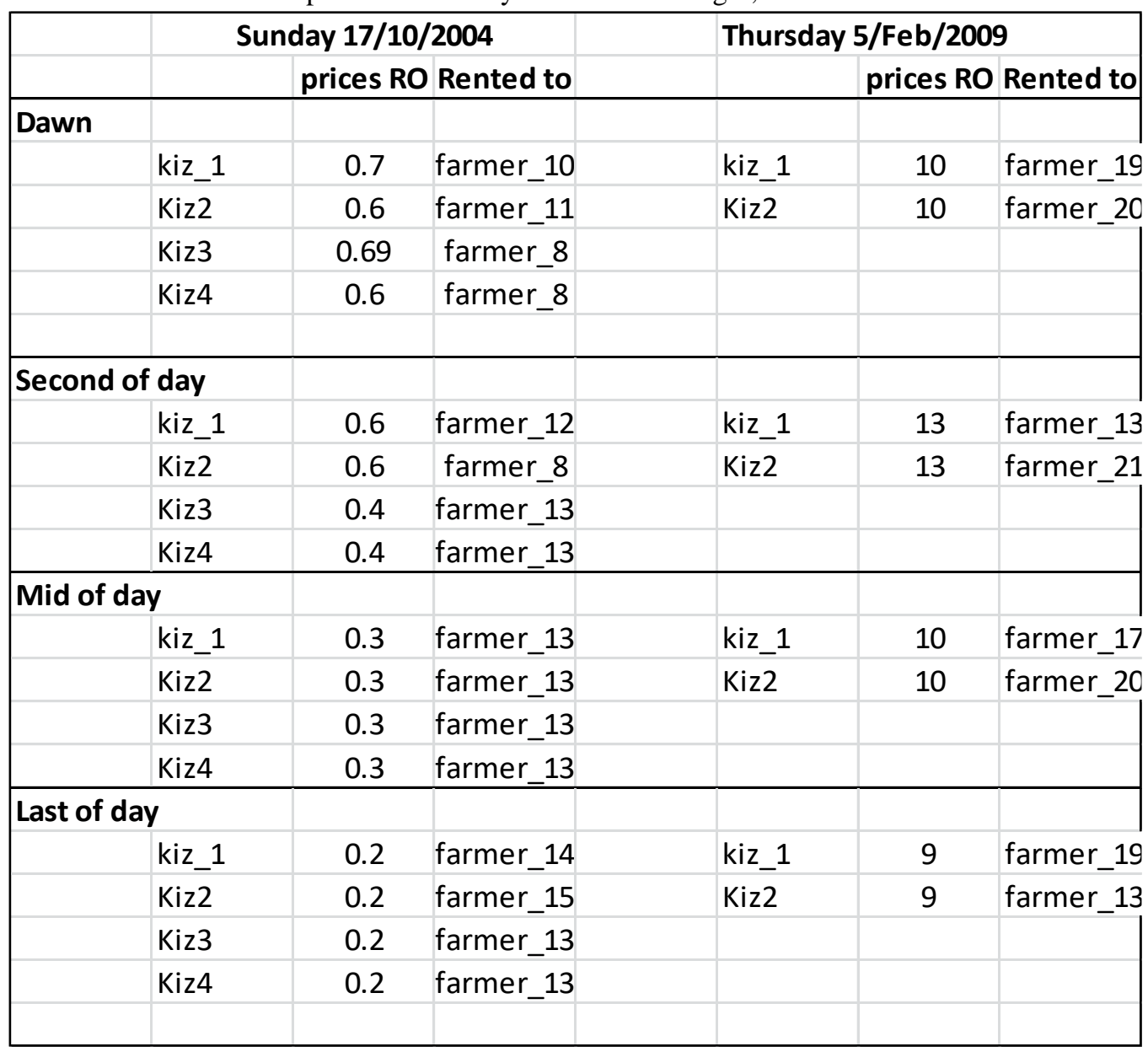


The two columns of data shown in Tables 4 and 5 indicate actual bidding prices for the years 2004 and 2009. These were selected from the time-serial data obtained from recorders for the purpose of analysing the two institutional arrangement scenario concerning falaj common right.

- Scenario one: during abundant of water flow, the common falaj right has $32 \mathrm{rub}$ ' $a$. This can be seen in Table 5 and 6 for the year 2004. In fact, Darisfalaj water flow recorded was high at 276litres per second (Aflaj Dept., 2009).

- Scenario two: during scarcity of water flow then falajDaris has only 16 rub'a. This can be seen in Table 4 and 5 for the year 2009. In fact, Darisfalaj water flow recorded was low at 47 litres per second (Aflaj Dept., 2009).

According to Tables 4 and 5 these two scenarios highly influence auction prices, as during 2009 prices were almost doubled than those obtained in 2004. This must be explained within the context of the rules applied during drought and abundant water supply of the two scenarios; during abundant of water flow the amount of the water available for renting is reduced, almost double of its availability during scarcity from 32 rub'a to 16 . This can be seen from the implicitly of the channel division, they say the auction carried out over two kiz as it was four during abundant of water flow. In addition, one can associate demand supply theory. First, as water supply became scarce in 2009there were very low bidding prices. This situation probably did not attract many potential bidders because of the low flow. In contrast, the supply of water was high in2004, which attracted many potential bidders and as a result prices were almost doubled. Second, the administrative agents applied the two institutional arrangement of reducing the amount of water to be rented as discussed above. This was interpreted as being in line with the demand-supply theory in the sense that they are trying here to make some sort of restriction on the supply in order to maintain the demand and as a result avoid market failure. Finally, the bidding in the water market is conducted not on the basis of volume of water but on the flow of water in the channel at the time of auctioning. For this reason, the factor of drought is taken into consideration and hence the water flow is implicitly divided into four portions, locally known kiz.

\section{Annual Rented Falaj Rights}

Beside the weekly common falaj rights, there are certain water rights referred to as 'murboutah', meaning 'fixed or surrounded to their leases. That is the right to use water for a period of time in this case one year. According Mr. Hilal Al Esmaili there are two types of murboutah water rights:those which can be auction annually, comprise of 19.5 ather and those which are fixed in the hands of the known renters, comprised of 2.5 ather. Once these the water flow derived from these rights are rented on the annual auction then:

- No one can take them even the wakeel

- The right to use the water will be passed to the leasee once he or she pays the rent for a one-year period.

- The right to use water can be inherited if the renter die then members of their family will continue to use the right over the agreed year.

\section{Waqf Rights}

The survey reveals that Waqf water rights (plural awqaf); meaning endowments, hold a particular meaning within the Omani institutionalcontext. It representsthree main regulatory aspects. First, it historically passed from certain charity agent or person, whether passed away or alive to particular charitable agents like mosque, school students, the poor etc. Second, must not be changed or sold to another agent. Third, must be invested and the derived income ought to be distributed with accordance to the written historical document through administrative agent. In summary, the waqf rights can be classified as assets by which historically passed to charitable agents in order to use derived income.

Many types of endowments have been identified including mosques, water rights, education and schools, the poor, food for fasters etc. According to Table 3waqf rights constitute 8.5 baddah out of the 17 for falajDarisor 50 percent of all the rights. Thus, waqt play a major role within the day-to-day activities in terms of decision-making and transactions.

Detailed information obtained from the two Daris wakeels and the director of the waqffor Nizwa centre reveal that the 8.5 baddah, which is equivalent of 204 athers are distributed and documented as follows: the revenue gained from selling athers musts be used for the following purposes. i) 10 athers to support the poor; ii) 12 to support student students ofreligion (Islam?) in the village of Nizwa; iii) 5 athers to support students studying in Nizwa; and iv) 12 athers to support students studying at Nizwa but coming from abroad.

The remaining rights (which comprise 165 athers) are distributed between two different categories. The first is assigned to farms which are attached to particular mosques. According Mr. Hilal there are 300 of these farms. However, the wakeel provided detail information for only six cultivated farms, which, as indicated are under his management. The others are managed by others whom were difficult to interview. The following farms are considered as waqf farms received waqf water rights:

These are as follows:

a) farm 1 with 24 athers,

b) farm 2 with 6 athers, 

c) farm 3 with 20 athers,
d) farm4 with 17 athers,
e) farm5 with 8 athers, and
f) Farm6 with 8 athers, for a total of 83athers.

The second category, including cemetery, protecting walls and fasting takse the remaining 82 athers.

According to the interview conducted with the manager of the Department of Awqf in the regional centre in the town ofNizwa, the athers allocated for students and teachers used to be rented annually to farmers and the revenue then distributed annually to these students. However, at present these are rented to farmers, but the revenue has been accumulated in an account of the Bank of Muscatunder governmental control. The reason for this is not known.

\section{Bayt-El-Mal Water Rights}

The Bayt-el-malis another important institution within the social organizational structure of the Omani society. Historically, it was a very important component of the wealth distribution within the village settlement structure, as it provided the revenue to cover the settlement expenses. However, current it operated and collected by the current government, in fact, the survey reveal it is controlled and operated under the Director General of Awqaf and Bayt-elmal, Ministry of Awqaf and Religious Affairs. AlBusaidi(2002) differentiated between awqaf and bayt-almal in the sense that the revenue from the awqaf must be distributed according to the directions laid down in the original document bequeathing the asset while the latter revenue must go to the relevant state department to form part of general revenue.

Data collected from the above-mentioned Department and the two falajDaris wakils reveals that a total of 4 baddah, equivalent to a total of 96 athers are bayt-el-mal rights. Hence, according to these records the flows from these rights are distributed as follows: i) 19.5 athers are rented on an annual auction; ii) 2 athermurboutah rented annually to particular farms at anagreed upon price; iii) 48 athers (two baddah) are rented on the weekly auction; and iv) the remaining 26.5 athersgoes to irrigate Bayt-el-mal farms. In fact information obtained from the service wakeel indicated that there are a total of 21 Bat-Mal farms which require irrigation water of 125.5 athers (see Appendix 5). The wakeel revealed that the remaining water is bought on the falaj'sweekly auctions.

\section{Private Water Right}

Like the waqf and Bayt-el-mal water rights, private water rights have a particular meaning within the context of Omani falaj institutional arrangements.

According to the two wakils there appear to be institutions concerning the selling and buying of the private water rights. These can be summarized as follows.
- Whenever a transaction takes place it must be based on the situation of drought. That is with accordance to the circumstances of the water flow on the main channel; on half the water flowing in the channel can be bought or sold. In practice, they implicitly divide the flow over the channel into kiz (portion), hence they say eight kizmust be reduced into four during scarcity or drought. For example, if the flow is measured on eight small portions of flow, referred to locally as khaz, then the selling and buying is conducted upon onlyhalf of these eight (i.e. four khaz). This means the transactor of say eight atherswill be allowed to extract or take half of the falaj flow: that is four ather based on the scarcity circumstances.

- This institution is unwritten, as the wakils responded negatively to a question of whether a document is kept to indicate this important water transaction. They responded, "Most of the shareholders know this through customary rules." They went on to say, "Writing this down may confuse people and it is rather better to know it customarily as the water is fluctuating."

Within falaj Daris private rights makes up. 4.5baddah or approximately $14 \%$ of the total baddah (Table 3 ). Although these rights constitute a relatively small portion of all rights with the falaj, they are supply more than 205 farmers according to a list provided by Areef Nasser b. Said AlKindi. The distribution varies widely as follows: there are 89 farmers with less than half an ather, 90 farmers have half and one ather, and 26 farmers have more than one ather.

Locally there is an important exchangeable term very often used to refer a private right:Aseela (which means genuine). They try to relate all these private rights to the historical and the original sources. During interviews with members of the community the term Assela is more appropriate to use than the other term mulk (means ownership) He attributed this to the fact those water rights which lie within the boundary of the community and must be historical documentation preserved. The survey reveals that the documentation of these rights is highly protected and passed from generation to generation. A well-known person, Khamis b. said AlSaiyfi, possesses the falaj Daris book. A special visit was arranged to view the book. It is a very old book written during the time of Imam Sultan b. Saif Al-Yaru'abi (1672) and contains all the rights for waqt, common, private and Bat_mal (see Fig. 4). 


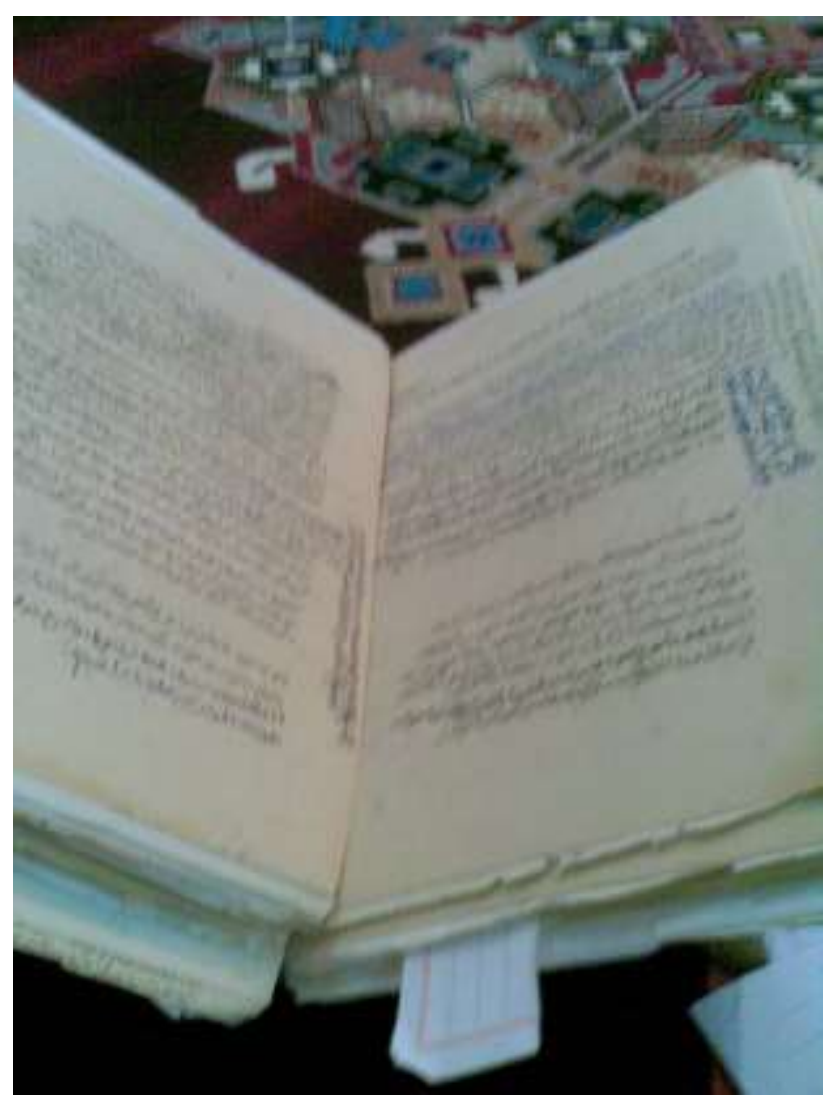

Fig. 4: The original recorded book for all Falaj Daris water rights

\section{Discussion and Conclusion}

The fast body of literature concerning the possibility to assert private ownership to a watercourse, discussed in section two, can be linked with the revealed survey result. Probably the revealed results for the falaj daris institutional arrangements have reflected upon this link from two main prospective. First, the difficulty to use a measuring unit over a watercourse in order to transact water rights (Dales, 1968) . Second, the present of risk variable, which is associated with fluctuations in water supply, and how to overcome this? These can be discussed from the two main finding; the raddat measuring unit and the existing of the customary legal system.

The first perspective of the use of raddaht can be viewed as the prevailing and forming the based on the institution for private ownership. This has overcome the problem of a watercourse being fleeting resource, mobile and so large that it makes it difficult to use a measurable unit. Probably the use of time, ather (reflect the shade of a stading person and how water flow over in accordance to the movement of the sun) rather than the use of volume (qiyas).

The second perspectives can be further discussed using the revealed result on the customary arrangement to overcome

${ }^{8}$ Stage one is where any given resource is un-owned, unmanaged, and open to all. Stage two is where the resource is less plentiful and is appropriated the watercourse supply fluctuation. We are in favour with the developed stages by Rose $(1991)^{8}$ on how water can be transferred through three main stages as it become scarcer. We belief is the significance of stage two where the resource becomes less plentiful, and where property rights begin, and where customary arrangements (implemented) by a group start to begin. Furthermore, it is important to view the present of the legal system over the development of institutional arrangements. The Arabic word "urf", which means custom, has particular implication within the Muslim community. Kamal (1991) indicated that within the Islamic legal system there is room for two sources of opinion and speculative analogy. This shows that the Islamic laws, which are based on judicial opinion or on speculative analogy, have often been based on prevailing customs. For example, Kamali(1991) demonstrated the use for the concept of 'custom' within changing circumstances that might occur in society, where it was stated that "it is permissible to depart from the custom on which they were founded if it changes in the course of time" (pg. 285). This is exactly how the private water rights and other rights operated over the flow of the Daris water fluctuation as this investigated over the revealed results.

\section{References}

Abdel Rahmnn HA and Omezzine A (1996) Aflaj water resources management: tradable water rights to improve irrigation productivity in Oman. Water International 21 (2): 70-75.

Aflaj Dept MORMAWR (2009) Aflaj water flow In: Aflaj Dept, D. G. O. W. R. M. (Eds.). Muscat: Ministry of Regional Municipalities and Water Resources

Al-Busaidi MBK (2002) Personal consideeration of waqf, Ministry of Awqaf and Religouse Affairs, Sultanate of Oman.

Al-Ghafri ATIATN (2001) Irrigation Scheduling of Aflaj of Oman: Methods and Modernization. 2001 (ed).: Graduate School of Agriculture, Hokkaido University, Japan

Araral E (2009) The failure of water utilities privatization: Synthesis of evidence, analysis and implications. Policy and Society 27(2): 221-228.

Bjornlund H (2003) Efficient water market mechanisms to cope with water scarcity. International Journal of Water Resources Development 19(2): 553 - 567.

Brajer V \& Martin WE (1990) Water Rights Markets: Social and Legal Considerations: Resource's 'Community' Value, Legal Inconsistencies and Vague Definition and Assignment of Rights Color Issues. American Journal of Economics and Sociology 49(2): 35-44.

by a group. Stage three begins when the resource is scarce enough to be subject to full-blown individualized property rights. 
Bromley DW (1982) Land and Water Problems: An Institutional Perspective. American Journal of Agricultural Economics 64(2): $834-844$.

Dales JH (1968) Land, Water, and Ownership. The Canadian Journal of Economics / Revue canadienne d'Economique 1(2): 791-804.

Dietz, T., Ostrom, E. \& Stern, P.C (2003). The struggle to govern the commons. Science, 302(2): 1907-1912.

Easter KW, Rosegrant MW and Dinar A (1999) Formal and informal markets for water: Institutions, Performance, and Constraints. The World Bank Research Observer 14(1): 99-116.

Kamali MH (1991) Principles of Islamic Jurisprudence. Islamic Texts Society (UK)

Megdiche-Kharrat F, Moussa M and Rejeb H (2017) Aflaj' Water Management in Oman: The Case of Falaj Al-Khatmeen in Birkat Al-Mouz, Wilayat Nizwa. In: Ouessar M, Gabriels D, Tsunekawa A \& Evett S (eds.) Water and Land Security in Drylands: Response to Climate Change. Cham: Springer International Publishing.

Megdiche-Kharrat F, Ragala R \& Moussa M (2016) The Aqueducts of the Sultanate of Oman Sustainable WaterSupplying Systems Irrigating Oases Cities. Underground Aqueducts Handbook. CRC Press.

Milliman JW (1959) Water Law and Private Decision-Making: A Critique. Journal of Law and Economics 2(2): 41-63.

Milliman JW (1965) Economic Considerations for the Design of Water Institutions. Public Administration Review 25(2): 284-289.

MRMWR (2000) Statitical and infontory of the aflaj in Sultanate of Oman.

Nash H (2008). Water Management: the use of stars in Oman.
Norman WR, Shayya WH, AL-Ghafri AS \& Mccann IR (1997) Aflaj irrigation and on-farm water management in northern Oman. Irrigation and Drainage Systems 12(2): $35-48$.

North DC (1991) Institutions. The Journal of Economic Perspectives 5(2): 97-112.

Perry C (2001) Water at any price? Issues and options in charging for irrigation water. Irrigation and Drainage 50(2): 1-7.

Randall A (1981) Property Entitlements And Pricing Policies For A Maturing Water Economy. Australian Journal of Agricultural Economics 25(2): 195-220.

Randall A (1983) The Problem of Market Failure. Natural Resources Journal 23(2): 131-148.

Rose CM (1990) Energy and Efficiency in the Realignment of Common-Law Water Rights. The Journal of Legal Studies 19(2): 261-296.

Rutherford M (1995) The Old and the New Institutionalism: Can Bridges Be Built? Journal of Economic Issues 29(2): 443451.

Saleth RM \& Dinar A (2005) Water institutional reforms: theory and practice. Water Policy 7(2): 1-19.

Walliman NSR (2006) Social research methods, London, SAGE.

Wilkinson JC (1977) Water and tribal settlement in South-East Arabia. A study of the Aflaj of Oman, Clarendon Press, Oxford.

Young RA (1986). Why Are There so Few Transactions among water users. American Journal of Agricultural Economics 68(2): 1143-1151.

Zekri S \& AL-Marshudi AS (2008) A millenarian water rights system and water markets in Oman. Water International 33(2): 350-360. 